Boise State University ScholarWorks

Civil Engineering Faculty Publications and

Presentations

Department of Civil Engineering

5-22-2011

\title{
Effects of Coupling in Understanding the Surface Energy Balance in the Snake River Basin, Idaho
}

Thilinl Jaksa

Boise State University

Kevin Nuss

Boise State University

Venkataramana Sridhar

Boise State University

This is an author-produced, peer-reviewed version of this article. The final, definitive version of this document can be found online at Proceedings of the 2011 World Environmental and Water Resources Congress, published by American Society of Civil Engineers. Copyright restrictions may apply. DOI:10.1061/41173(414)121 


\title{
Effects of Coupling in Understanding the Surface Energy Balance in the Snake River Basin, Idaho
}

\author{
ThilinI Jaksa, Kevin Nuss, and Venkat Sridhar \\ Boise State University
}

\begin{abstract}
An accurate estimation of surface fluxes and evapotranspiration is critical in understanding the hydrological and meteorological processes linking the land and the atmosphere. Due to difficulties in obtaining extensive and timely field measurements, land surface and atmospheric models are widely employed in estimating such fluxes. This study focuses on testing the ability of Noah LSM to simulate the surface fluxes both in an uncoupled mode and coupled within an atmospheric model. An agricultural area in the Snake River Basin in Idaho and its surrounding natural vegetation regions are the study area. Two model improvements are tested in this investigation: modification to the calculations of the surface exchange coefficient and the addition of an irrigation scheme to increase available water to crop areas. Results show that these changes are significant factors in proper modeling of hydrological and atmospheric process, but improvements and additional calibration to different regions are still needed.
\end{abstract}

\section{Introduction}

Noah and Weather Research and Forecasting (WRF) are state of the science physically-distributed models used to investigate the land surface and atmospheric characteristics. Noah is already a part of WRF because the interactions between the atmosphere and earth are critical in accurately forecasting the weather. One of the two most important interactions is the exchange of heat and moisture between the surface and atmosphere. The diurnal fluctuations in temperature alter the balance between these two systems. Evapotranspiration (ET) which is the movement, or flux, of water returning to the air as evaporated water from moist surfaces or from within plants is one of the most complex but important variables to quantify either through models or through observing systems.

Weather and land surface models account for soil moisture and provide useful information to quantify water movement and its management, under normal and extreme conditions including drought and flooding. To do so effectively, the models need to track the water balance of incoming rainfall versus water loss from ET, surface run off, and subsurface flow. This study focuses on a component of the ET loss but also adds an irrigation algorithm to the models as an additional source of incoming water in cropland areas. First, a change suggested by Chen and Zhang (2009) was added to the calculation of the exchange coefficient that couples surface vegetation to the atmosphere. Data from instrumented grass and shrub vegetation sites is used to measure and evaluate the effect as a general enhancement for all vegetation types. The site dominated by cheatgrass (Bromus tectorum) is near Raft River, Idaho and the other dominated by sagebrush (Artemisia tridentata) is near Hollister, Idaho.

We investigate the effects of a n ewly added irrigation scheme in this paper to evaluate if this enhancement is useful to quantify the water balance in the Snake River basin. The physical formulation in the existing version of the model does not correctly represent the croplands in the semiarid region of southern Idaho, which has very little annual precipitation. Therefore irrigation, the main human induced change in the area, is incorporated into the existing LSM in order to obtain better estimates of both water and energy budget components. When enough water is available for ET, some of the incoming solar energy is converted to latent heat, which increases humidity, rather than sensible heat, which in turn increases air temperature. Water returning to the air as latent heat is no longer available for filling rivers and aquifers. 
This is an author-produced, peer-reviewed version of this article. The final, definitive version of this document can be found online at Proceedings of the 2011World Environmental and Water Resources Congress, published by American Society of Civil Engineers. Copyright restrictions may apply. DOI: 10.1061/41173(414)121

Wind speed is modeled using equations relating speed to an air height above a theoretical height near the ground, called $z_{0 m}$, where the speed is zero. Similarly, there is a theoretical height, called $z_{0 t}$ which is usually below $\mathrm{z}_{0 \mathrm{~m}}$, where the air temperature is the same as the ground surface. Calculating the heat flux depends on estimating $\mathrm{z}_{0 \mathrm{t}}$ correctly because the distance the heat travels between differing air temperatures, affects the rate. Previous versions of WRF and Noah used a fixed parameter, based on empirical studies, to calculate $z_{0 t}$. This research uses a method described in Chen and Zhang (2009) which makes adjustments to $\mathrm{z}_{0 \mathrm{t}}$ based on the height of the underlying vegetation.

\section{Methods}

\subsection{Weather Research and Forecasting (WRF) model and Noah LSM}

Weather Research and Forecasting (WRF) is a state of the art weather forecasting model and is used for research and operational purposes. Simulation by WRF in the coupled land surface atmospheric conditions links the feedback processes more explicitly as the temperature and water movement occurring at and just below the ground's surface are dynamically linked.

The High Resolution Data Assimilation System (HRLDAS v3.1) infrastructure is used to run the Noah LSM in the uncoupled mode at $4 \mathrm{~km}$ spatial resolution and one hourly temporal resolution with some changes. Noah v3.2 is used with the new equation related with the surface exchange coefficient. An irrigation scheme is introduced to improve the summertime fluxes over croplands.

Both the coupled and uncoupled models use inputs from the North America Regional Reanalysis (NARR) data set. WRF uses two domains outside the area of interest to downscale the atmospheric data. All three domains are shown in Figure 1. For WRF, the large outermost domain, having 98 rows and $89 \mathrm{c}$ olumns, uses $36 \mathrm{~km}$ grid cells to resolve the incoming NARR data within the model representation. The middle domain helps resolve orographic effects by using $12 \mathrm{~km}$ grid cells in 102 rows and 114 columns. The innermost domain, which is the same for both the couple and uncoupled models, covers the main area of interest with 66 rows and 81 columns. Within WRF, the $4 \mathrm{~km}$ grid cells help resolve convective processes.

The WRF V3.2.1 model setup uses 38 vertical grid cells of varying heights, with the lowest having an average height of $36 \mathrm{~m}$. Other WRF parameterization details include: Lin microphysics scheme, RRTMG shortwave and longwave schemes, ETA similarity surface layer scheme, Noah land surface scheme, MYJ PBL scheme, Grell 3D ensemble cumulus scheme, two way nesting, positive definite advection, and simple diffusion.

The main WRF simulations spanned March 1, 2010 through September 30, 2010. The Noah LSM was run at hourly time steps from January 2009 through September 2010 leaving the first 12 months as a spin up period (Chen et al., 2007). Simulated surface fluxes and soil moisture data was used for the analysis. The common fields shared by both coupled and uncoupled modes are land use, soil types, elevation, land-water masks and monthly vegetations fields. 

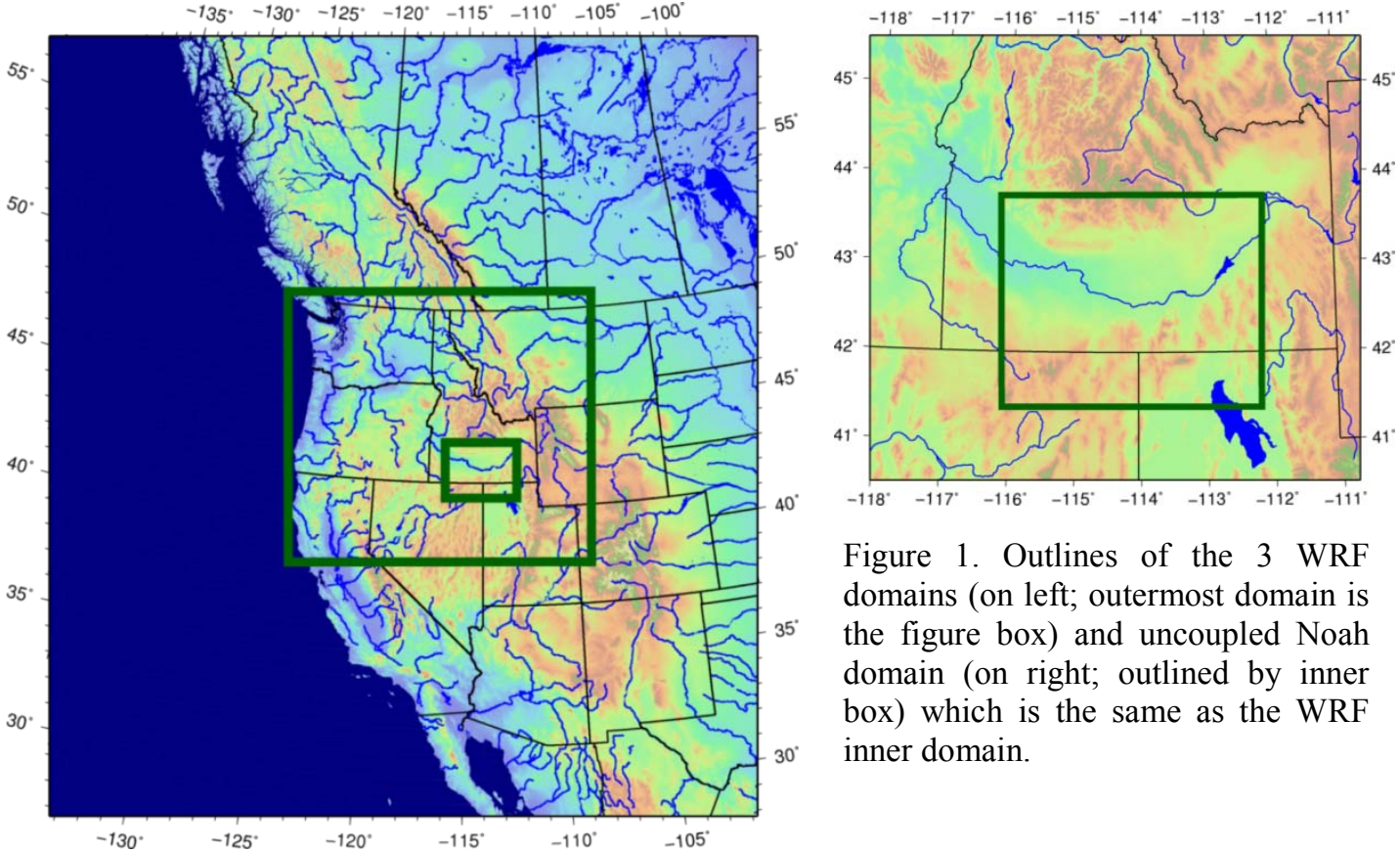

Figure 1. Outlines of the $3 \mathrm{WRF}$ domains (on left; outermost domain is the figure box) and uncoupled Noah domain (on right; outlined by inner box) which is the same as the WRF inner domain.

\subsection{Irrigation Scheme}

Both sprinkler and surface flooding are common irrigation methods in the modeled area. Although the human behavior and equipment of actual irrigation is very complex and diverse, the implemented irrigation scheme is designed to have some characteristics of both. Only the grid cells having a land use classified as irrigated cropland are subjected to irrigation. There are three adjustable parameters: 1) minimum percentage of soil moisture (MinPCT), which serves as an irrigation trigger, 2) the start date of the irrigation season, and 3$)$ the end date. The second soil layer $(10-40 \mathrm{~cm}$ deep) is used to trigger irrigation rather than the thinner top layer, which is prone to quick drying in the summer. The second layer's available soil moisture is compared to the minimum soil moisture (MSM) to determine if irrigation is required. MSM is defined by:

$$
\mathrm{MSM}=(\mathrm{SMCREF}-\mathrm{SMCWLT}) * \mathrm{MinPCT}+\mathrm{SMCWLT}
$$

Where SMCREF is soil's reference moisture capacity and SMCWLT is the wilting point. The dates May $1^{\text {st }}$ through September $15^{\text {th }}$ were chosen for the irrigation season based on estimated crop water use data from AgriMet weather stations.

First, it is decided if the current simulation date is within the irrigation season and if the grid is classified as irrigated cropland. Then the second soil layer's available soil moisture is compared with MSM. And if too low, the top layer is brought up to the soil's maximum moisture capacity, the saturation level, as done by Adegoke et al. (2003) and Evans and Zaitchik (2008) even though there are some other differences between the methods. The minimum percentage (MinPCT) used in this study is $50 \%$, which is a recommended for many crops as the depletion level at which to start irrigation. Saturating the top layer allows some water to flow to the soil layers below. Application inefficiencies such as runoff, wind drift, and evaporation are not estimated with this scheme and adequate water is assumed to be available. 


\section{Surface Exchange Coefficient}

The surface exchange coefficient, $\mathrm{C}_{\mathrm{h}}$, which uses the aerodynamic and thermal roughness lengths, is an important parameter in LSMs because it affects the heat transfer between the land surface and the atmosphere. Several studies have found that the Noah LSM tends to overestimate sensible heat flux with the existing $\mathrm{C}_{\mathrm{h}}$ equations (Chen et al., 2010; Hogue et at., 2005; LeMone et al., 2008). Within Noah, the thermal roughness length, $\mathrm{z}_{0 \mathrm{t}}$, is first calculated according to Zilitinkevich (1995) as

$$
\mathrm{z}_{0 \mathrm{t}}=\mathrm{z}_{0 \mathrm{~m}} * \exp \left(-\mathrm{kC}_{\mathrm{zil}} \sqrt{ } \mathrm{R}_{\mathrm{e}}\right)
$$

where $\mathrm{z}_{0 \mathrm{~m}}$ is the aerodynamic roughness length based on the vegetation category, $\mathrm{k}$ is the von Karman constant, and $\mathrm{C}_{\mathrm{zil}}$ has a constant value of 0.1 in the existing model. The new formulation for $\mathrm{C}_{\mathrm{zil}}$, as proposed by Chen and Zhang (2009), is used here and derives $\mathrm{C}_{\mathrm{zil}}$ from the aerodynamic roughness length, $\mathrm{z}_{0 \mathrm{~m}}$, of the vegetation type:

$$
\mathrm{C}_{\mathrm{zil}}=10^{\left(-0.4 * \mathrm{z}_{0 \mathrm{~m}} / 0.07\right)}
$$

Derived $\mathrm{C}_{\mathrm{zil}}$ using the above equation is always higher than the default value 0.1 . Mean value of $\mathrm{C}_{\mathrm{zil}}$ for April is 0.25 which is reduced to a mean value of 0.14 for July but still higher than 0.1 . Using $z_{0 \mathrm{~m}}, \mathrm{z}_{0 \mathrm{t}}$, and current atmospheric conditions, WRF and Noah LSM calculate the surface exchange coefficient. Figure 3 shows the variation of $\log C_{h}$ using the new equation for $C_{z i l}$ in WRF and Noah models with the new formula when compared with observations at the Hollister (HL) shrub land and Raft River $(\mathrm{RR})$ grassland sites.

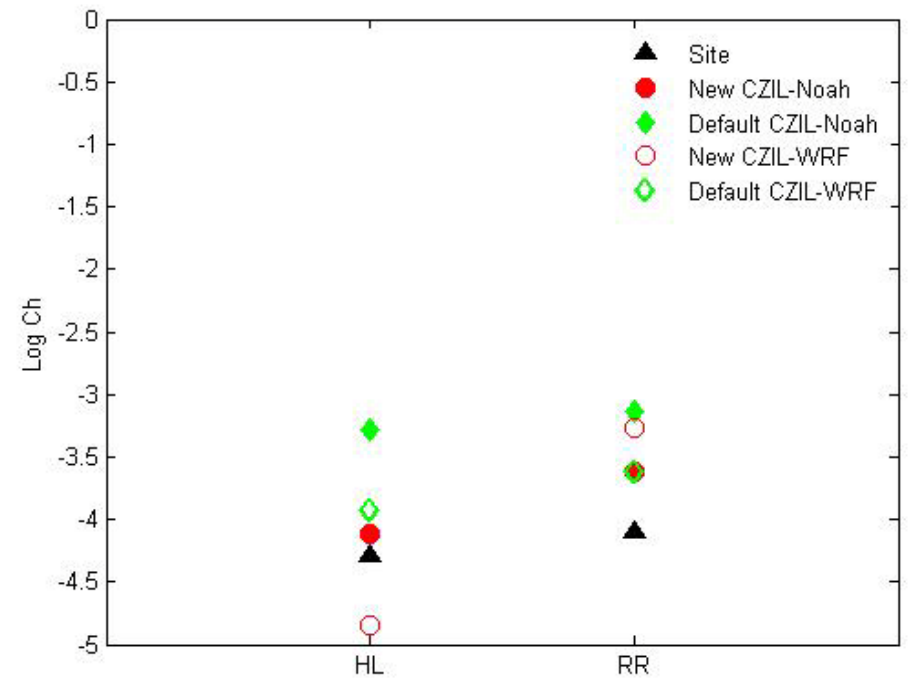

Figure 3. Changes in the exchange coefficient, $C_{h}$, with new $C_{z i l}$ formulation.

\section{Results}

\subsection{Effects of Irrigation}

In Figure 4, the spatial plots from the uncoupled Noah simulations illustrate the pattern of monthly ET totals for the area of interest, both with and without irrigation. The increased ET in crop areas, which are generally along the river curving across the center of the plots, is made possible by water from the newly implemented irrigation scheme. Some additional ET is even seen in months before the irrigation begins, apparently from soil moisture remaining from the previous growing season. The most dramatic contrast occurs in the hot summer months when the natural vegetation areas have dried out, but the irrigated areas have available water for both direct evaporation from the soil and for plant transpiration. For an example, in July average monthly total ET for cropland grid cells was increased to $199 \mathrm{~mm}$ in the Noah LSM and to $118 \mathrm{~mm}$ in WRF using the irrigation scheme. The same without irrigation was 
This is an author-produced, peer-reviewed version of this article. The final, definitive version of this document can be found online at Proceedings of the 2011World Environmental and Water Resources Congress, published by American Society of Civil Engineers. Copyright restrictions may apply. DOI: 10.1061/41173(414)121

$30 \mathrm{~mm}$ for Noah LSM and $100 \mathrm{~mm}$ for WRF. Table 1 shows the monthly total ET averaged for cropland grid cells from March to September.
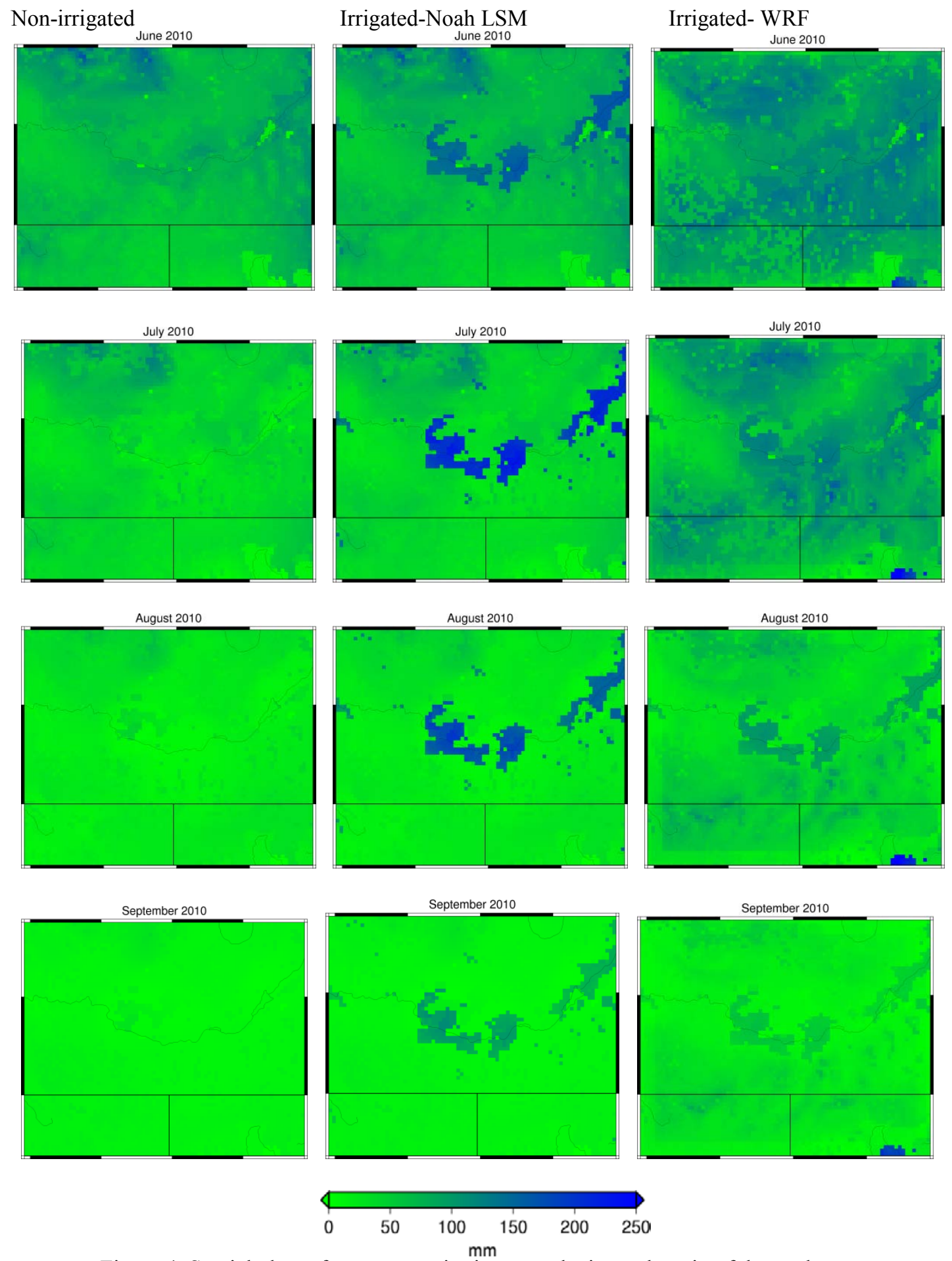

Figure 4. Spatial plots of evapotranspiration over the inner domain of the study area 
This is an author-produced, peer-reviewed version of this article. The final, definitive version of this document can be found online at Proceedings of the 2011World Environmental and Water Resources Congress, published by American Society of Civil Engineers. Copyright restrictions may apply. DOI: 10.1061/41173(414)121

Table1. Mean monthly total evapotranspiration of cropland grid cells in millimeters

\begin{tabular}{|l|c|c|c|c|}
\cline { 2 - 5 } \multicolumn{1}{c|}{} & \multicolumn{1}{c|}{$\begin{array}{c}\text { Noah } \\
\text { Non-Irrigated }\end{array}$} & $\begin{array}{c}\text { Noah } \\
\text { Irrigated }\end{array}$ & $\begin{array}{c}\text { WRF } \\
\text { Non-Irrigated }\end{array}$ & $\begin{array}{c}\text { WRF } \\
\text { Irrigated }\end{array}$ \\
\hline March & 27.30686 & 34.87301 & 26.24666 & 26.27751 \\
\hline April & 49.14288 & 60.55764 & 47.59344 & 47.93052 \\
\hline May & 75.24857 & 98.59694 & 75.21595 & 76.02143 \\
\hline June & 87.67767 & 149.08010 & 99.34651 & 101.74130 \\
\hline July & 29.84670 & 198.94850 & 100.36070 & 118.50350 \\
\hline August & 13.51829 & 157.76580 & 52.66610 & 90.56921 \\
\hline September & 9.842969 & 84.21098 & 18.71877 & 49.11565 \\
\hline
\end{tabular}

\subsection{Surface Energy Balance Analysis}

Sensible heat flux and latent heat flux were analyzed with the observed data at Raft River and Hollister. According to the time series plots (not shown here), the models capture the diurnal trend, but over the grasslands at Raft River, they tend to overestimate SH under summer conditions while underestimating $\mathrm{SH}$ over the shrub lands at Hollister during spring. With the use of new $\mathrm{C}_{\mathrm{zil}}$, error in sensible heat at both sites is reduced in Noah runs while WRF shows both reduced and increased error as shown in Figure 5. As an example, mean observed sensible heat flux at Hollister was $69 \mathrm{Wm}^{-2}$. Using the new formulation for $\mathrm{C}_{\mathrm{zil}}$, the sensible heat flux was reduced from $84 \mathrm{Wm}^{-2}$ to $61 \mathrm{Wm}^{-2}$ for WRF while the reduction for Noah LSN was from $87 \mathrm{Wm}^{-2}$ to $70 \mathrm{Wm}^{-2}$. In the case of latent heat flux, WRF shows reduced error in all months at Hollister but increased error at Raft River. Error has been reduced in the spring months in Noah LSM but in the summer, June shows increased error with the new equation. 


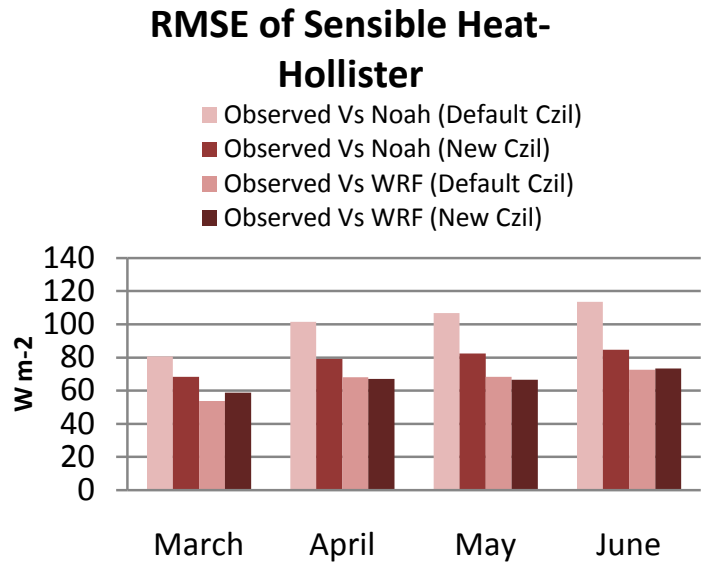

RMSE of Latent Heat - Hollister

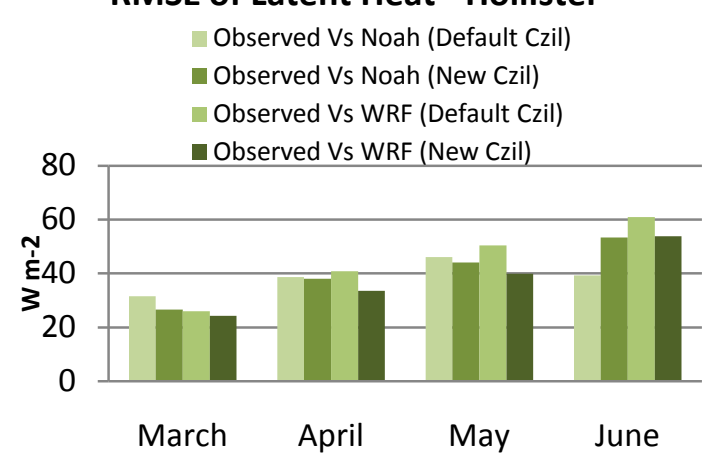

RMSE of Sensible Heat - Raft River

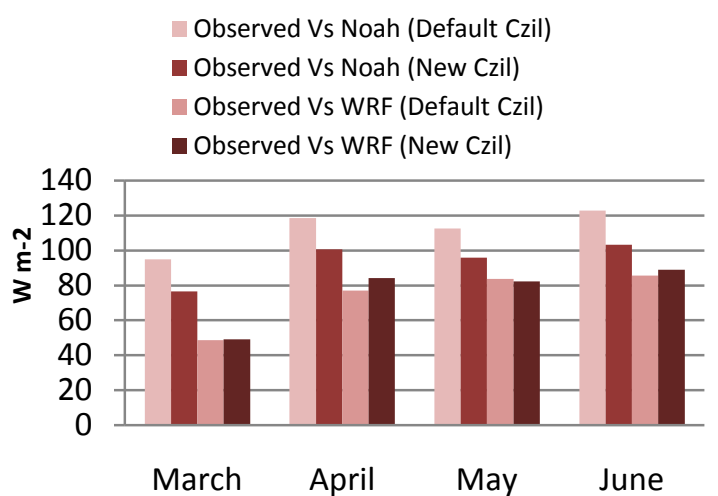

RMSE of Latent Heat - Raft River

Observed Vs Noah (Default Czil)

- Observed Vs Noah (New Czil)

- Observed Vs WRF (Default Czil)

- Observed Vs WRF (New Czil)

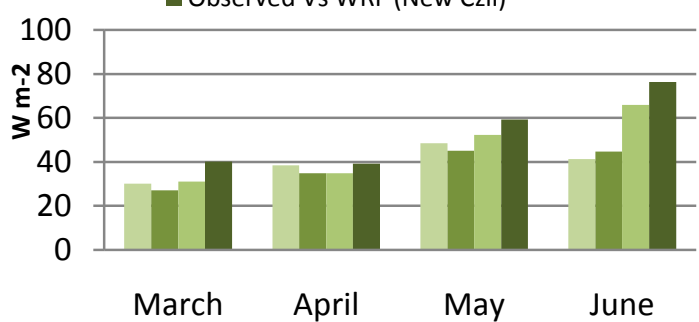

Figure 5. Root mean squared error of latent and sensible heat fluxes compared against the observations with default value and the new values of $\mathrm{C}_{\text {zil }}$.

\subsection{Soil Moisture Content}

WRF simulations were run both with and without a five month wintertime spin-up period. Atmospheric models are much more computationally expensive than uncoupled LSMs so reducing simulation time before the period of interest is beneficial. For the time period and the cropland location used for analysis, the soil moisture data provided by NARR for March 2010 is very similar to the soil moisture calculated after simulating a winter of snow accumulation and melt. The differences are quickly reduced as the models converge when the snow cover depletes during the late spring season.

Even though the uncoupled Noah simulation resolves to similar top layer soil moisture content in early March 2010, it quickly diverges, becoming drier. This was unexpected and may either be caused by NARR's temperatures which are warmer than those computed by WRF or caused by the lower soil layers being drier and allowing quicker percolation downward. Both models arrived at soil moisture noticeably lower than the field capacity for the soil type, even during March when root uptake by plants is minimal (Figure 6). 


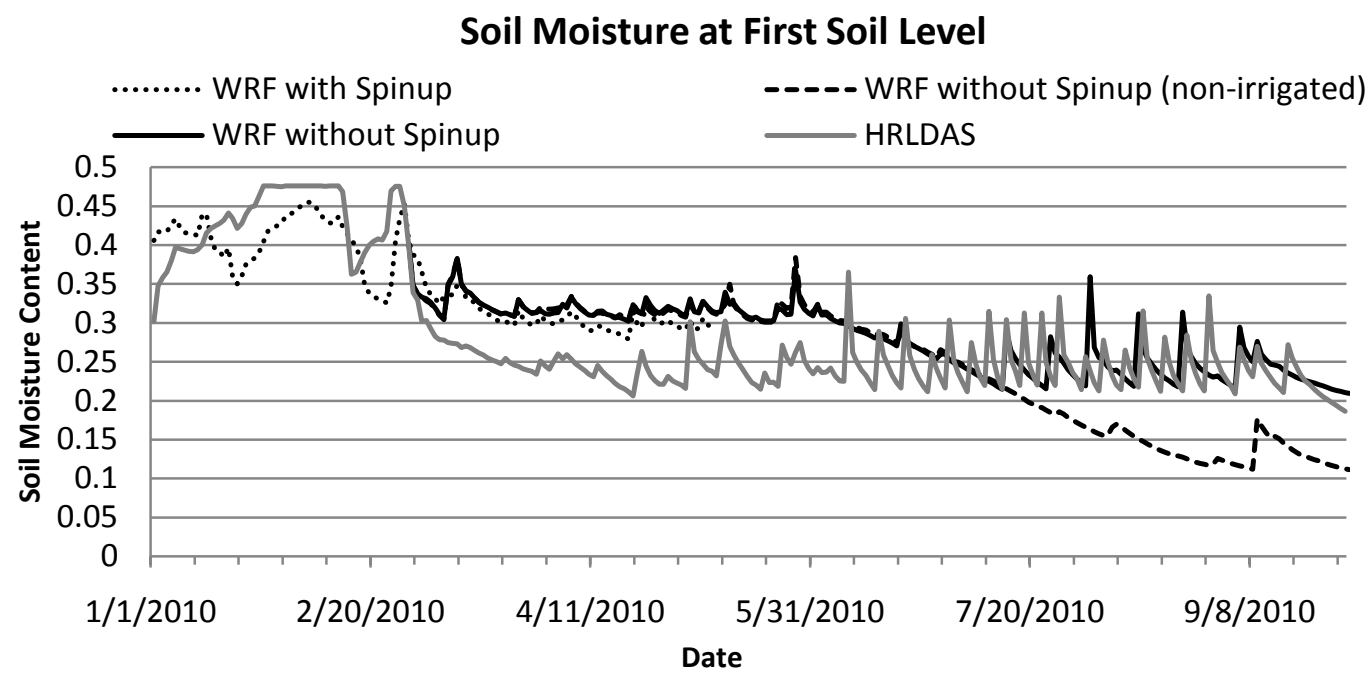

Figure 6. Volumetric moisture content at the first soil level

\section{Conclusions}

Use of the new formulation for the coefficient $C_{\text {zil }}$, as introduced by Chen and Zhang(2009), for use in the Zilitinkevich (1995) equation improved the calculation of the surface and atmosphere coupling strength, even though the calculated error of sensible and latent heat exhibits different patterns, depending on the month. In order to partition the incoming energy accurately, deriving this exchange coefficient for the vegetation types that are typical to Idaho proved critical.

Representation of human induced changes in cropland areas via the irrigation scheme, improved the estimation of surface energy balance components, primarily evapotranspiration and sensible heat flux during the growing season. Such improvements will be crucial for current and future research of hydrology processes in this area.

Our investigation also revealed that improvements made to the existing WRF model are also helpful in distinguishing the evolution of boundary layer across the Snake River Basin that are partly influenced by the advection from the surrounding dry, semi-arid regions of Western Idaho and Eastern Oregon. Accurate characterization of diurnal fluctuations in the boundary layer depth serves to quantify precipitation feedbacks influenced by evapotranspiration from the irrigated areas of the Snake River Basin. 


\section{References}

Adegoke, J.O., R.A. Pielke, J. Eastman, R. Mahmood, and K.G.Hubbard (2003). "Impact of Irrigation on Midsummer Surface Fluxes and Temperature under Dry Synoptic Conditions: A Regional Atmospheric Model Study of the U.S. High Plains", Journal of Monthly Weather Review, 131, 556-564.

Chen, F., and Y. Zhang (2009). "On the coupling Strength between the Land Surface and the Atmosphere: From Viewpoint of Surface Exchange Coefficients", Geophysical Research Letters, 36, L10404, doi:10.1029/2009GL037980.

Chen, F., and Coauthors, (2007). "Description and Evaluation of the Characteristics of the NCAR High-Resolution Land Data Assimilation System", Journal of applied Meteorology and Climatology, 46,694-713.

Chen, Y., Yang, K., Zhou, D., Qin, J., and Guo, X. (2010). "Improving the Noah Land Surface Model in Arid Regions with an Appropriate Parameterization of the Thermal Roughness Length", Journal of Hydrometeorology, 11, 995-1006.

Evans, J.P., and B.F. Zaitchik (2008). "Modeling the Large-Scale Water Balance Impact of Different Irrigation Systems", Water Resources Research, 44, W08448, doi:10.1029/2007WR006671.

Hogue, T.S., Bastidas, L., Gupta, H., Sorooshian, S., Mitchell, K., and Emmerich, W., (2005). "“ Evaluation and Transferability of the Noah Land Surface Model in Semiarid Environments", Journal of Hydrometeorology, 6, 68-84.

LeMone, M.A., Tewari, M., Chen, F., Alfieri, J., and Niyogi, D. (2008). "Evaluation of the Noah Land Surface Model Using Data from a Fair-Weather IHOP_200 Day with Heterogeneous Surface Fluxes", Monthly Weather Review, 136, 4915-4941.

Zilitinkevich, S.S. (1995). "Non-Local Turbulent Transport: Pollution Dispersion Aspects of Coherent Structure of Convective Flows, Air Pollution III, H. Power, N. Moussiopoulos, and C.A. Brebbia, Eds., Vol. I, Air Pollution Theory and Simulations, Computational Mechanics Publications, 53-60. 